\title{
The Effectiveness of the RAFT Strategy in Developing Creative Writing Skills of Eighth Grade Students in Public Schools
}

\author{
Adel Mouneer Abo El Rous \\ Assistant Professor, Faculty of Education, Qatar University, Qatar \\ *E-mail of corresponding author: adel.rous@qu.edu.qa \\ Abla Ahmad Desouky \\ Professional Development Specialist, Faculty of Education, Qatar University \\ Nehal Azmey Al Hertane \\ Professional Development Specialist, Faculty of Education, Qatar University
}

\begin{abstract}
The creative writing is very important for students; where it develops their imagination and helps them choose the vocabulary in which to express their ideas. The RAFT strategy is useful to develop students' creative writing skills. The current research aimed to identify the effectiveness of the RAFT strategy in developing the creative writing skills of eighth-grade students in public schools in the State of Qatar. The research sample consisted of two groups: the controlled group and the experimental one. Each group contained (46) male and female students from the eighth grade. The RAFT strategy was applied to the experimental group students. The traditional method was also applied to the students of the control group. The students of the two groups were also pre-and post-tested in the creative writing skills test. The results of the research revealed that there were statistically significant differences between the mean scores of the students of the control group and students of the experimental group in the post-test of creative writing in favour of the experimental group. The research also recommended employing the RAFT strategy to develop creative writing skills in different educational stages.
\end{abstract}

Keywords: RAFT strategy - creative writing - Arabic language

DOI: $10.7176 / \mathrm{JEP} / 12-32-03$

Publication date: November $30^{\text {th }} 2021$

\section{Introduction}

The environment around children is an important factor for children to acquire their first language. It encourages them to integrate and to use language naturally with family members around them and the outside world. Children can acquire the skills of listening and speaking through continuous experience and practice with parents and peers. Schools give a great interest in developing listening and speaking skills, in addition to teaching reading and writing in the early educational stages. (Hemmeter\& Kaiser, 1990) (Min, 2015).

Children are prepared to learn to read and write within the environment around them. A new stage in teaching children's different concepts and language skills begins and children are prepared educationally and linguistically to learn reading and writing. More emphasis should be placed on the two written skills (reading and writing) in later educational stages. Writing is one of the most important language skills that a person learns to write down all his works, ideas, and culture.

The Arabic language is creative, and its distinctive features confirm the availability of fluency, flexibility and originality factors. The development of students' creative linguistic performance skills is in line with the nature and characteristics of the Arabic language. Creative linguistic usage provides an opportunity to develop mental processes and thinking patterns, and to show learners' linguistic abilities and talents. (Abd Elqader \& Ismaeel, 2015). "Encouraging students to write well is an opportunity for every teacher to provide a contemplative atmosphere in the classroom. Students' writing is an area that is increasingly overlooked day by day. This cannot be avoided unless the teacher carefully reads everything the students wrote and comments on their writings (Hilfish \& Smith, 2012).

Creative writing is one of the most important language skills as it expresses feelings and feelings clearly. Accordingly, creative writing is an important element that needs a variety of teaching strategies and methods; to achieve education goals. (Dakhel, 2018). Writing is one of the most difficult language skills. While writing, students don't just share their thoughts; rather, they must choose the appropriate vocabulary to express these thoughts. (Anggraini\& Usman, 2017, 20)

\section{Research problem:}

Several studies have confirmed that one of the reasons for students' weakness in creative writing is following traditional teaching methods. That may even be the direct cause of students' poor level of creative writing. Attention should be paid to creative writing, with an emphasis on appropriate teaching methods that take into 
account the interests and language level of students. Objective standards that accurately measure aspects of writing should also be developed. Reliance on teacher correction without relying on correction standards; will be characterized by the subjectivity of the teacher that affects the correction process. (Dakhel, 2018) (Qatamee\& Allozey, 2008) (Zaier, Dakhel, 2016).

Since writing is one of the most important requirements for language teaching and learning; It is one of the language skills that students rely on for academic achievement, as well as a tool of expressing their thoughts and feelings. Writing is a fertile field for showing students' ingenuity and their linguistic and intellectual creativity. This necessitates the need to address this problem and to intensify effective research to find innovative solutions in this field. (Al Ahwal, 2018)

Some studies recommended paying attention to develop creative writing skills among students, and confirmed significant weakness of students in creative writing. This calls us to use appropriate educational methods and effective teaching strategies to develop students' creative writing skills. (Al-Shammari\& Al Hashemi, 2018). The effective factor in students' writing competence may be the strategy that the teacher uses in teaching writing. In traditional teaching, the teacher rarely brainstorms his students while they are writing to stimulate their ideas before expressing them in written form. The teacher often allows his students to work on their own without giving them any instructions to develop their ideas and to express them properly (Parilasanti, Suarnajaya, \& Marjohan, 2014)

Previous studies also confirmed that students in eighth grade face a problem in building paragraphs, preparing and organizing ideas, and how to write key and supporting sentences. The studies emphasized that the RAFT strategy is a good way to help students in solving the problems they encounter while writing. (Idayanti.2014). Taha \& Azahrani, 2020, confirmed the effectiveness of (RAFT) strategy in developing creative writing skills for female students. Most students face many difficulties in writing paragraphs, and the inability to express their ideas well, especially while organizing their ideas into a coherent written structure (Abedelqader, 2017). It is important to train students how to produce ideas, and how to organize them in pages. Writing requires good knowledge to help students write their thoughts in meaningful sentences (Cho and Schunn, 2007).

Previous studies have also confirmed the poor level of students in general in creative writing skills, especially in the preparatory stage. This is due to automated practices that are no longer effective and cannot achieve the expected results. This prompted finding alternative solutions to develop students' creative writing skills. (Khasawneh, 2012) (Alisa\& Rosa, 2013) (Mukhaiyar\& Rajab, 2013) (Parilasanti et al, 2014) (Widiyati, 2014) (Riyaanti, 2015) (Partiwi, 2016) (El Sourani, 2017).

Students' weaknesses in creative writing skills have been confirmed by revising students' marks on periodic written tests. In addition, students do not have a clear strategy to rely on in organizing their thoughts while writing an essay. Moreover, teaching practices still using traditional teaching strategies. In addition, most teachers do not know anything about RAFT strategy or how to use it to organize students' ideas, and train them on correct writing. All previous studies confirmed that RAFT strategy is effective in organizing students' thoughts before writing. Results of these studies demonstrated the effectiveness of the RAFT strategy in developing creative writing skills. (Idayanti.2014) (Parilasanti, Suarnajaya, \& Marjohan, 2014) (Abedelqader, 2017) (Taha\& Azahrani, 2020)

There are various strategies that teachers can employ it to develop students' creative writing skills. RAFT strategy is one of the most important strategies used to develop students' writing skills. Therefore, the researchers used this strategy in the current research to develop creative writing skills for eighth-grade students.

One of the most important problems students face is a lack of motivation while writing. It is therefore important to use the RAFT strategy in teaching because it stimulates students' motivation towards writing. (Ganinda, 2020, 4). The RAFT strategy is one of the instructional strategies used to develop students' writing skills. The RAFT strategy encourages students to use their imagination to explain what they are writing using well-structured steps. The students use their creativity to display ideas from their imagination and creative skills; to give the subject a unique perspective. (Dani et al, 2018).

\subsection{Research questions:}

The current research problem was determined in the following declarative statement: Effectiveness of RAFT strategy in developing creative writing skills of eighth grade students in the State of Qatar. The following two questions are derived from this statement:

1- What are the appropriate creative writing skills for eighth grade students?

2- How effective is the RAFT strategy in developing the creative writing skills of eighth grade students?

\subsection{Research hypotheses:}

(1) There are no statistically significant differences on the scale $(0.01)$ between the mean scores of the students of the control group and the students of the experimental group in the creative writing pre-test.

(2) There are statistically significant differences on the scale (0.01) between the mean scores of the students of 
the control group and the students of the experimental group in the creative writing posttest in favour of the experimental group.

(3) There are statistically significant differences on the scale (0.01) between the mean scores of the experimental group students in creative writing pre and posttests in favour of the post-test.

\section{Research objective:}

Determining the effectiveness of RAFT strategy in developing creative writing skills of eighth grade students in public schools in the State of Qatar.

\section{Significance of the Research:}

- Employing RAFT strategy in teaching writing as it is considered one of the important strategies in developing creative writing skills.

- Benefiting from creative writing skills test to determine the students' creative writing skills level.

- $\quad$ Employing RAFT strategy in developing some social skills among students, such as: cooperation, social interaction, responsibility, views exchange, and respecting others' opinions.

\section{Study Delimitations:}

5.1. Objective Delimitations: The application of the research was limited to determining the effectiveness of the RAFT strategy for developing creative writing skills.

5.2. Spatial Delimitations: The research was applied to eighth-grade students in Doha Preparatory Schools for Boys, and Maria Al-Qibtia Preparatory School for Girls in Doha, State of Qatar.

5.3. Temporal Delimitations: The research was applied for three months, starting from February 2019 until the end of April 2019.

\section{Terms of the study:}

6.1. The RAFT Strategy:

The RAFT Strategy is a system that helps students in writing to understand their roles just like authors, identify their audience and the suitable forms that they will use, and the subject they will write about. These key components must be included in each writing assignment.

\subsection{Creative writing:}

We defined creative writing as: an intellectual, emotional, and linguistic activity that contains a set of ideas that are well organized by the student to reflect with the emotional attitudes, which is well formulated. It should have the element of originality, fluency, flexibility, expansion and sound writing to influence the recipient and can be measured through a test prepared for this purpose, called "Creative Writing Test".

\section{The Theoretical framework:}

\subsection{The RAFT Strategy:}

The RAFT strategy refers to $(\mathrm{R})$ stands for Role, which is the role of the writer that the student should assume, (A) refers to Audience, which means to whom the students will write this topic, (F) means Format, which means what the writing will look like (message, complaint, essay, conversation, memo, magazine), and the letter (T) refers to the topic and it needs to be persuaded by strong ideas and words indicating the event (Santa, 1988). RAFT is an active learning strategy. The strategy requires that the learner be active in the educational process because the learner is an important participant in this strategy. (Al-Dulaimi\& Hussain, 2020). The RAFT strategy is one of the most important strategies in teaching; because it develops students' reading comprehension while reading. (Abd et al, 2020, 636). The study by Abbas \& Abd Al-Sahib (2021), confirmed the effectiveness of the RAFT strategy in developing the reading and writing skills of fourth-grade literary students at the secondary stage in Iraq.

The RAFT strategy is a directed writing strategy. It encourages students to think more deeply about the topic they are writing about and to whom they will direct their writing. The purpose of implementing RAFT is to teach students a new way of thinking about their writing. (Pratiwi, 2016). RAFT strategy relies on integrating new information with previous experiences and responding to the text through writing. Therefore, the RAFT strategy focuses on four elements: the writer, the audience, the writing form, and the topic (CCRS Quarterly Meeting, 2014).

The RAFT strategy is used in teaching student-oriented writing and to improve their writing efficiency. RAFT strategy is a system to help students understand the key elements of organizing their writing (Abedelqader, 2017). Students experience a small amount of anxiety while using RAFT and this prompts them to write. As for students who suffer from a high rate of anxiety, this is a hindrance to them because of their fear of failing to write, and this confirms that the RAFT strategy plays a good role in reducing students' anxiety (Parilasanti, 
Suarnajaya, \& Marjohan, 2014).

Based on the above, the RAFT strategy is characterized by:

(1) Develop a sense of responsibility and independent learning while writing the topic of expression.

(2) Strengthening social interaction among students; It makes students cooperate while writing a common topic within the same group, and this leads to the exchange of experiences between students.

(3) Developing students' skills in speaking and presentation; Where students practice presenting the written topic.

(4) Training students to present their ideas in an orderly fashion; where one topic is divided into several elements.

Despite these advantages of RAFT strategy, there are weaknesses that may appear while using RAFT strategy, which are:

1- Some students may not have the ability to produce and organize ideas in a good way, and therefore their writing may be confused and not subject to logical base.

2- Some students may not interact with their colleagues in exchanging ideas related to the topic they will write about, and this may be due to the personal nature of some students; They tend to be isolated, and not interact with others.

3- Students may be poor in writing, and this may delay them in writing about their peers in the class.

Despite all this, the teacher can overcome the weaknesses of RAFT strategy. Any strategy comes with some weaknesses, but the teacher should employ this strategy in a purposeful manner, leading to the benefit of students in the development of creative writing skills.

Learning process is an effective process, in which the student can establish meaningful relationships between new information and experiences stored in his mind. A good educational strategy motivates learners to build these relationships during the learning process. (Morison, Ros\& Kimb, 2012).

\subsection{Creative writing:}

Al Hardani defines it as: the human ability to comprehend a specific subject, try to rewrite it in a new way without imitation and characterized by creativity. Imagination and emotion are employed, and language is taken into account from the morphological and grammatical points of view. (Al Hardani, 2013).

Writing is an important ability in the language learning process. Some students are not satisfied when they are asked to practice the language orally, so writing is an educational tool for these students to express what they think through their production on paper without disturbance or anxiety (Rivera \& Pinilla, 2017).

Writing is not an individual process. It is a social skill that involves observing, telling stories, communicating, building ideas, and providing new solutions to the challenges we face. Writing is a means of self-expression. It is one of the most important skills that contains imagination, and it is also a good way to share our thoughts with others, to know oneself better, and discover the strengths of students (Olehlova \& Priedite, 2016) (Chen, 2017)

Writing is divided into two types:

1. Functional writing: It includes the life situations that a person is exposed to in his day, and related to different jobs and professions. It needs formal writings, devoid of emotion and feelings, and focusing on the direct and clear style. This type includes writing daily transactions, reports, scientific research and official correspondences between individuals, companies, and official institutions in the state.

2. Creative writing: It focuses on expressing feelings and emotions in a literary style. It is also created by the writer, and it varies from person to person depending on his/ her feelings, experiences, and the topic he/ she is writing about. (Fijal, 2010).

Functional writing and creative writing are not completely separated from each other. They often overlap. The functional expression may include creative aspects. Also, some areas of writing may include functional and creative writing. (Al-Basess, 2011).

Creative writing is characterized by the ability to construct structures and sentences, construct meaning through context, select vocabulary, and employ figurative language. Creative writing also engages students in writing more complex language structures. It also leads to the development of language proficiency. In addition to integrating students into a range of roles such as: thinker, artist, maker and trainee. Students' subjective perspectives are developed culturally and stylistically, and students' awareness of their local, cultural and linguistic identity is developed (Barbot et al, 2012) (Adam \& Babiker, 2015) (The Quality Assurance Agency for Higher Education, 2017).

Creative writing contains several sub-skills:

1) Fluency: It is the ability to generate a large number of ideas, whether verbal or non-verbal, when responding to a specific stimulus, and the speed in producing them.

2) Flexibility: It is the ability to generate diverse, not expected, ideas, change the course of thinking with the change of stimulus, and not be intolerant of predetermined ideas. 
3) Originality: It is the ability to produce rare, useful, and unrelated ideas. It is the characteristics most associated with creativity and thinking.

4) Elaboration: the ability to add new and diverse details to a particular idea; This leads to its development, as well as the ability to provide explanations for unfamiliar topics.

5) Sensitivity to Problems: It means that some individuals have a faster awareness than others in noticing problems and verifying their presence in a particular situation. (Abu Jabeen, 2011).

\section{Previous Literature:}

There have been many previous studies that dealt with RAFT strategy in developing writing skills in general, and creative writing skills in particular among students at different academic levels, and they were presented as follows:

Khasawneh, (2012), aimed to determine the effectiveness of the RAFT strategy in developing some spelling concepts for fourth-grade students in the city of Taif. The study found the effectiveness of the RAFT strategy in developing some spelling concepts for fourth-grade students. (Alisa \& Rosa, 2013) also employed RAFT strategy in developing functional writing skills among secondary school students in Indonesia; In order to develop these students' English language skills. She emphasized that employing the RAFT strategy led to the development of students' attention during writing, in addition to the exchange of ideas during functional writing.

Mukhaiyar \& Radjab (2013), focused on determining the effectiveness of RAFT strategy in developing the writing skills of first-year students in the Department of English, College of Education in Sumatra, Indonesia. The study found that there were statistically significant differences in the post-test for writing the paragraph between the two groups: experimental and control, in favour of the experimental group that used the RAFT strategy. (Parilasanti, Suarnajaya, \& Marjohan, 2014) also aimed to verify the effect of the RAFT strategy in reducing the level of anxiety and developing the editorial competencies of students in Indonesia. The researchers concluded that the students of the experimental group who used the RAFT strategy outperformed the students of the control group who used the traditional method in writing skills. Also, training on RAFT strategy led to a decrease in anxiety among the students of the experimental group. Because they are trained to organize their thoughts while writing.

Widiyati (2014), focused on determining the effectiveness of the RAFT strategy in developing students' writing skills through their innovative thinking skills in Indonesia. The study found that the RAFT strategy was more effective than instructional writing for teaching writing skills to students in the English Department. The study (Riyaanti (2015), also confirmed that seventh-grade students in some schools in Indonesia used the RAFT strategy, and were more enthusiastic about writing and that the RAFT strategy was effective in developing the writing skills of these students.

ABD Elaal (2016), also aimed to determine the impact of RAFT strategy for developing environmental values and creative writing skills for second-year secondary school students. The researcher used the quasiexperimental method. The research sample consisted of (60) female students in the second grade of a secondary school in Egypt. The study concluded that the RAFT strategy is effective in developing environmental values and creative writing skills for female students.

Pratiwi (2016), aimed to determine the effectiveness of training students on RAFT strategy in developing their skills in writing Procedure Texts in the second grade of secondary school in Indonesia. The results of the study showed that there was an improvement in the students' skills in writing procedural texts after teaching expression to them using the RAFT strategy.

El Sourani (2017), aimed to identify the effectiveness of the RAFT strategy in developing English writing skills for tenth-grade female students in Palestine. The study found that there were statistically significant differences in learning English writing skills between the two groups: experimental and control, in favour of the experimental group that used the RAFT strategy.

Fawziah (2017), aimed to determine the impact of RAFT strategy in developing writing skills of Islamic middle school students in Indonesia. The study found a positive effect of RAFT strategy in developing the writing skills of eighth-grade students in middle school in Dar Al-Hekma in Indonesia.

The study of Al-Mahdawi\& Al-Smadi (2019), aimed to determine the effectiveness of the RAFT strategy in developing creative writing skills in English for eleventh graders in Jordan. The experimental group consisted of 25 students, and the control group consisted of 25 students. The experimental group was studied using the RAFT strategy, and the control group was studied using the traditional method. The results of the study showed that the students of the experimental group outperformed the students of the control group. This indicates the effectiveness of the RAFT strategy in developing students' creative writing skills.

Intharakasem\& Boonhok study (2019), aimed to determine the effectiveness of the RAFT strategy in developing creative writing skills in English for students of the College of Education at the University of Bangkok, Thailand. The study confirmed the effectiveness of the RAFT strategy in developing the creative writing skills of these students. 
Al-Maliki's study (2020), aimed to determine the impact of the RAFT strategy in developing reading comprehension skills and written expression skills for second-grade students in middle schools in Iraq. The study sample consisted of two groups: the experimental (34) students, and the control group (34) students. The experimental group was taught using the RAFT strategy, while the control group was taught using the traditional method. The results of the study showed that the students of the experimental group outperformed the students of the control group in the reading comprehension test, and the written expression test. This indicates the effectiveness of the RAFT strategy in developing students' reading comprehension skills and written expression skills.

Hidayah (2020), study aimed to measure the effectiveness of the RAFT strategy for developing narrative text writing skills in English for eighth graders in Indonesia. The pre and post tests for writing narrative text skills were applied to 30 students. The study found an improvement in the students' narrative text writing skills after using the RAFT writing strategy.

Kabigting (2020), study focused on determining the effect of the RAFT strategy on the English writing performance of tenth graders in the Philippines. The study used the pre and post tests to determine the students' level of written performance. The study confirmed the effectiveness of the RAFT strategy in developing students' writing performance skills.

Seliem et al (2020), study focused on determining the effect of the RAFT strategy in developing creative writing skills in English for third-year students in the preparatory stage in Egypt. The study sample consisted of eighty students. The study sample was divided into two groups: the experimental group (40) students and the control group (40) students. The experimental group used the RAFT strategy, and the control group used the traditional method. The creative writing test was applied before and after; to measure the creative writing skills of the study sample. The results of the study confirmed the effectiveness of the RAFT strategy in developing creative writing skills for the students of the experimental group.

Taha \& Azahrani (2020), also aimed to determine the effectiveness of the RAFT strategy through the Blackboard system in developing creative writing skills and the trend towards a child literature course for female student teachers at the College of Education at King Khalid University in Saudi Arabia. The research sample included the control group (40) female students, and the experimental group (40) female students. The results confirmed the effectiveness of the RAFT strategy through the Blackboard system in developing creative writing skills and the trend towards a children's literature course.

The study of Ola Ranjilita (2021), aimed to determine the effect of using the RAFT strategy in developing analytical text writing skills in English for eleventh-grade students in Indonesia. The study sample consisted of 32 male and female students. The students used the RAFT strategy in the writing of analytical texts. The pre-test and post-test were applied to the research sample. The results of the study confirmed the positive effect of using the RAFT strategy in developing students' skills in writing analytical texts.

\subsection{Comments on previous studies:}

Previous studies have used the RAFT strategy in different educational stages. These studies confirmed the effectiveness of the RAFT strategy in developing creative writing skills, despite the different ages of the students. This study is distinguished as the first study in the State of Qatar to use the RAFT strategy to develop the creative writing skills of students in the eighth grade.

\section{Research sample:}

The research sample was chosen intentionally. The research was applied to two groups: An experimental group (46 male and female), and the other is A control group (46 male and female). The application was implemented in Doha Preparatory School for Boys and Maria Al-Qibtia Preparatory School for Girls. The equality of the two groups was also taken into account in the age and academic average of the students, in addition to the teachers who teach these students.

\section{Research tools:}

\subsection{List of creative writing skills:}

The researchers prepared a list of creative writing skills. The list was presented to seven arbitrators specialized in curricula, teaching methods and assessment. The list has been modified by deletion, modification and addition. The list included (18) skills. (18) skills were distributed into (5) domains: originality: comprising (4) skills, fluency: comprising (4) skills, flexibility: comprising (3) skills, expansion: comprising (3) skills, and writing Sound: It includes (4) skills.

\subsection{Creative writing skills test:}

The researchers designed a creative writing skills test; they prepared a test in the subjective essay. It contained two different questions on which students should write an essay topic in these two topics. The time allotted to 
answer the test was calculated, which is (60) minutes. A form for correcting students' answers was also prepared. The overall test score was (95).

10.2.1. Test validity:

The researchers presented the initial image of the test to a group of arbitrators in the field of curricula, teaching methods, measurement and evaluation to verify the validity of the test and its relevance to the objective for which it was designed. The researchers asked the arbitrators to express their opinion on the clarity of the wording and the suitability of the test to the level of the students. The test has been modified in its final form according to the arbitrators' opinions.

10.2.2. Test stability:

Test reliability was calculated using the retest method; Where the tests were applied to (46) students other than the study sample. The test was re-applied to the same group fifteen days after the first application.

Table (1) Values of correlation coefficients between students' scores in the first and second applications of the

Creative Writing Test $(\mathrm{n}=46)$

\begin{tabular}{l|l} 
The first application of creative writing test & Pearson correlation coefficient (PCC)
\end{tabular}

The second application for creative writing test

** Statistically significant at level of 0.01 (with a confidence level of $99 \%$ ).

The results of the correlation coefficient between the scores of the first application and the second one showed a strong statistically significant correlation at the level of significance $(0.01)$ between the students' scores in the first application and the second application. It reached $(0.870)$ between the two applications of the creative writing test, which indicates the great stability that characterizes the creative writing test.

\section{Research Methodology:}

The research used the descriptive method and the quasi-experimental method. Data of creative writing skills list were collected. The researchers applied the creative writing test previously to the experimental and control group. The researchers used the RAFT strategy in teaching writing with the experimental group. The control group was also taught in the traditional way. The creative writing test was post-applied to the experimental and control group. The test application results were analyzed in order to interpret the results related to the effectiveness of the RAFT strategy in developing creative writing skills. The researchers used the following statistical methods: arithmetic means, standard deviations, frequencies and percentages.

\section{Checking equivalence of the two groups:}

The creative writing test was previously applied to the students of the two groups: the control and experimental. In order to check the equivalence of the two groups, the first hypothesis was formulated as follows:

There are no statistically significant differences at the level $(0.01)$ between the mean scores of the students of the control group and the students of the experimental group in the creative writing pretest.

The researchers used the Independent Samples T-Test to test the validity of this hypothesis, and to determine the significance of the differences between the mean scores of the students of the control group and students of the experimental group in the creative writing pre-test, the results came as in the following table:

Table (2) "T" value and levels of significance of the differences between the scores of the control group students and the experimental group students of in the pre-test for creative writing $(\mathrm{n}=92)$

\begin{tabular}{|c|c|c|c|c|c|c|c|c|}
\hline \multirow[t]{2}{*}{ Test } & \multicolumn{2}{|c|}{$\begin{array}{c}\text { Control group } \\
(n=46)\end{array}$} & \multicolumn{2}{|c|}{$\begin{array}{c}\text { Experimental group } \\
(n=46)\end{array}$} & \multirow{2}{*}{$\begin{array}{c}\mathbf{T} \\
\text { value }\end{array}$} & \multirow{2}{*}{\multicolumn{2}{|c|}{ Significance }} & \multirow[t]{2}{*}{ Differences } \\
\hline & A & M & $\mathbf{A}$ & $\mathbf{M}$ & & & & \\
\hline $\begin{array}{l}\text { Creative writing } \\
\text { pre-test }\end{array}$ & 51.43 & 8.13 & 53.74 & 7.71 & -1.395 & 0.167 & Insignificant & ------ \\
\hline
\end{tabular}

Function $=90$

1.987 Significant at 0.05 and 2.63 significant at .01

It is evident from Table No. (2) that the average scores of students in the experimental and control groups in the pretest creative writing. The average scores of the experimental group in the pretest were (51.43) and the average score of the control group was (53.74) and the value of (T) was (-1.395). It is a non-significant value at the significance level $(0.01$. this indicates that there are no significant differences between the mean scores of the students of the control group and the experimental group, and the average scores of the experimental group students in the creative writing pretest. Accordingly, the null hypothesis is accepted that: There are no statistically significant differences at the level $(0.01)$ between the averages of the scores of the control group students and the experimental group students in the creative writing pre-test.

\section{Results:}

\subsection{Results of the first question:}

To answer the first question: "What are the appropriate creative writing skills for eighth-grade students?". The 
researchers designed a questionnaire that includes a set of sub-skills, divided into five areas: originality, fluency, flexibility, expansion, and elements of sound writing. In order to verify the validity of the questionnaire, it was presented to a group of arbitrators in the field of Arabic language curricula and teaching methods. The questionnaire was modified to contain (18) skills. These skills were divided into five areas of creative writing skills, and they are presented in Table (3):

Table (3) List of creative writing skills for eighth grade students

\begin{tabular}{|l|l|}
\hline Domain & Skill \\
\hline Originality & 1- Write titles that only the student mentioned. \\
& 2- Writing ideas that were not mentioned except in his/her topic. \\
3- Employing words and sentences in an untraditional way. & - Using metaphors and rare similes. \\
\hline Fluency & $\begin{array}{l}\text { 1- Number of words written in the article. } \\
\text { 2- Discovering the different links between sentences such as: cause and effect } \\
\text { relationship, and contradiction. } \\
\text { 3- Provide logical evidence and arguments about the topic in the article. } \\
\text { 4- Use of artistic images expressing the subject. }\end{array}$ \\
\hline Flexibility & $\begin{array}{l}\text { 1- Varity and diversity of the subject's ideas. } \\
\text { 2- Diversity of linguistic methods expressing ideas. } \\
\text { 3- Giving logical explanations and conclusions to ideas. }\end{array}$ \\
\hline Expansion & $\begin{array}{l}\text { 1- Adding new elements to the subject that contribute to improving the written work. } \\
\text { 2- To elicit experiences and knowledge related to the subject. } \\
\text { 3- Adding new details to the topic. }\end{array}$ \\
\hline Elements of correct \\
writing & $\begin{array}{l}\text { 1- Organizing the essay content (introduction - content - conclusion). } \\
\text { 2- Use punctuation marks in appropriate place. } \\
\text { 3- Avoiding spelling errors. } \\
\text { 4- Avoiding grammatical errors. }\end{array}$ \\
\hline
\end{tabular}

Through Table No. (3), we note that the list of creative writing skills included (18) skills distributed over (5) domains. The domain of originality included (4) skills, the domain of fluency included (4) skills, the domain of flexibility included (3) skills, the domain of expansion included (3) skills, and the domain of sound writing included (4) skills.

\subsection{Results of the second question:}

To answer the second question: "What is the effectiveness of RAFT strategy in developing the creative writing skills of eighth-grade students?" The second hypothesis was formulated:

There are statistically significant differences at the level (0.01) between the mean scores of the students of the control group and students of the experimental group in creative writing posttest in favour of the experimental group.

The researchers used the Independent Samples T-Test to test the validity of this hypothesis, and to determine the significance of the differences between the mean scores of the students of the control group and students of the experimental group in creative writing posttest, the results came as in the following table:

Table (4) Value of " $\mathrm{T}$ " and levels of significance of the differences between the scores of the students of the control group and students of the experimental group in creative writing post-test $(n=92)$.

\begin{tabular}{|c|c|c|c|c|c|c|c|c|}
\hline \multirow[t]{2}{*}{ Test } & \multicolumn{2}{|c|}{$\begin{array}{l}\text { Experimental } \\
\operatorname{group}(n=46)\end{array}$} & \multicolumn{2}{|c|}{$\begin{array}{c}\text { Control group } \\
(n=46)\end{array}$} & \multirow[t]{2}{*}{ T value } & \multirow{2}{*}{\multicolumn{2}{|c|}{ Significance }} & \multirow[t]{2}{*}{ Differences } \\
\hline & $\mathbf{A}$ & M & $\mathbf{A}$ & M & & & & \\
\hline $\begin{array}{l}\text { Creative } \\
\text { writing post- } \\
\text { test }\end{array}$ & 79.91 & 3.92 & 66.28 & 7.54 & 10.876 & 0.001 & Significant & $\begin{array}{l}\text { in favour of } \\
\text { experimental } \\
\text { group }\end{array}$ \\
\hline
\end{tabular}

Function $=90$

1.987 significant at 0.05 level and 2.63 significant at level .01

It is clear from Table No. (4) The difference between the average scores of students in the experimental and control groups in the post-test of creative writing. The average scores of the experimental group in the post-test reached (79.91), while the average scores of the control group were (66.28), and the value of $(\mathrm{T})$ reached (10.876), which is a significant value at a significance level of (0.01) and a function up to a significance level (0.001). This indicates that there are significant differences between the mean scores of the students of the control group and the experimental group, in favour of the students of the experimental group in the post-test of creative writing. Accordingly, we reject the null hypothesis and accept the alternative hypothesis that: There are statistically significant differences at the level $(0.01)$ between the mean scores of the control group and the 
experimental group students in the post-test of creative writing in favour of the experimental group. These differences can be attributed to employing the RAFT strategy in teaching writing. The researchers used the eta square $\eta 2$ to clarify the size of the effect resulting from the use of RAFT strategy on the students' scores in the post-test. The following table shows the values of the eta square $\eta 2$ and the size of the effect.

Table (5) Eta square values $\eta 2$ and the size of the effect resulting from using RAFT strategy in developing creative writing skills $(\mathrm{n}=92)$

\begin{tabular}{|c|c|c|c|c|c|}
\hline Test & $\begin{array}{c}\text { Experimental } \\
\text { group mean }\end{array}$ & $\begin{array}{c}\text { Control group } \\
\text { mean }\end{array}$ & T value & 2 & Effect \\
\hline Creative writing post-test & 79.91 & 66.28 & 10.876 & 0.57 & Significant \\
\hline
\end{tabular}

$\mathrm{F}=90$

$\eta 2=0.14$ It indicates a significant effect size

It is clear from Table No. (5) the size of the significant effect of using the strategy on the difference in the scores of students in the experimental group from their peers in the control group, where the ETA value was greater than 0.14 , where the value of the test reached 0.47 , which indicates a very significant effect of using the strategy.

The third hypothesis is: There are statistically significant differences at the level $(0.01)$ between the mean scores of the experimental group students in the pre and post-tests of creative writing in favour of the post-test.

The researchers used Paired Samples T-Test to test the validity of this hypothesis and to determine the significance of the differences between the mean scores of the experimental group students in the creative writing skills pre and post-tests, the results came as in the following table:

Table (6) T value and the levels of significance of the differences between the scores of the experimental group students in creative writing the pre and posttests $(n=46)$, the values of the Cohen index and the effect size.

\begin{tabular}{|c|c|c|c|c|c|c|c|c|c|c|}
\hline \multirow{2}{*}{ Test } & \multicolumn{2}{|c|}{ post test } & \multicolumn{2}{|c|}{ Pre-test } & \multirow{2}{*}{$\begin{array}{c}\mathbf{T} \\
\text { value }\end{array}$} & \multirow{2}{*}{\multicolumn{2}{|c|}{ Significance }} & \multirow{2}{*}{ Differences } & \multirow[t]{2}{*}{$\begin{array}{l}\text { Cohen } \\
\text { index }\end{array}$} & \multirow[t]{2}{*}{ effect size } \\
\hline & $\mathbf{A}$ & $\mathbf{M}$ & $\mathbf{A}$ & $\mathbf{M}$ & & & & & & \\
\hline $\begin{array}{l}\text { Creative } \\
\text { writing }\end{array}$ & 79.91 & 3.92 & 51.43 & 8.13 & 27.716 & 0.000 & دالة & $\begin{array}{l}\text { In favour of } \\
\text { post tests }\end{array}$ & 4.13 & significant \\
\hline
\end{tabular}

Function $=45$

2.016 significant at 0.05 and 2.693 significant at $.01,3.528$ significant at 0.001

The value of the Cohen index is calculated from the following law:

$\mathrm{f}=\mathrm{t} / \sqrt{ } \mathrm{n}$, where $\mathrm{d}$ : Cohen index value, $\mathrm{t}$ : value $(\mathrm{t}), \mathrm{n}$ : sample size $(\mathrm{n})$.

If the result is: $d=0.2$, it indicates a small size effect

$\mathrm{f}=0.5$ it shows the average size effect

$\mathrm{f}=0.8$ it indicates a significant size effect

It is clear from the table the difference between the average scores of the students in the experimental group in the pre and posttests, where the average scores of the pre-test reached (51.43), while in the post-test it reached (79.91), and the value of $(\mathrm{T})$ reached (27.716), which is a significant value at the level of significance $(0.01)$ and also a function up to the significance level (0.001); Which indicates that there are significant differences between the average scores of students in the experimental group in creative writing pre and posttests. Accordingly, the null hypothesis is rejected and the alternative hypothesis is accepted that there are statistically significant differences at the level $(0.01)$ between the mean scores of the experimental group students in the two tests creative writing pre and post-test in favour of the post-test. These differences can be traced back to the students' training to use the RAFT strategy while teaching writing.

The researchers used Cohen's coefficient to clarify the size of the effect resulting from the use of RAFT strategy on the scores of the experimental group students in the post-test. Cohen coefficient has a value of greater than 0.8 and a value of 4.13 which indicates a very large impact of using the strategy.

\section{Discussion:}

The second and third hypotheses have been proven in the current study. This confirms the effectiveness of RAFT strategy in developing the creative writing skills of eighth-grade students in public schools, and this is what the current study agreed with: (Parilasanti, Suarnajaya, \& Marjohan, 2014) (Abedelqader, 2017) (Taha\& Azahrani, 2020) (Al-Mahdawi\& Al-Smadi, 2019) (Intharakasem\& Boonhok, 2019) (Seliem et al, 2020) (Ola Ranjilita, 2021).

This can be explained by the fact that we trained the students using the RAFT strategy; This had an impact on reducing the failure rate of these students. They were able to write about the elements of the subject easier. We also trained the students on how to organize their thoughts in a logical sequence. This led to understanding the topic they write about, and then expressing it in a more orderly manner, and this was confirmed by (Parilasanti, Suarnajaya, \& Marjohan, 2014) (Abedelqader, 2017) (Al-Maliki, 2020) (Hidayah, 2020) 
(Kabigting, 2020).

Students were also trained to integrate text's new information with their previous experiences stored in their minds. This is in addition to motivating the students towards writing the required topics. The topic has been divided into sub-elements, easy to write about. Applying the RAFT strategy led to the emergence of some social skills among the students during the implementation of the strategy. The students worked in groups during writing the required topic. Each group consisted of five students. This helped the students to interact socially with each other, exchange different experiences, and cooperate in order to complete the task that was assigned to them. This was confirmed by the study of (Olehlova \& Priedite, 2016) (Chen, 2017).

Writing is a sociolinguistic activity that needs more than one person in order to exchange ideas. This emphasizes the importance of the social aspect during the implementation of the strategy that gives students the chance to exchange ideas, including: social interaction between members of the same group, views acceptance, and some self-skills that appeared among students such as: self-confidence, sense of responsibility, and cooperation towards achieving the goal. Also, writing in a social environment reduces anxiety and fear among students, and this is what the current study agrees with the study of: (Parilasanti, Suarnajaya, \& Marjohan, 2014).

Students were able to express their ideas logically. So, students who excel at producing and organizing their ideas are also good at creative writing. The students were also warned that they might make some linguistic mistakes while writing and they were reassured that it is normal. The important thing is not to repeat the same mistakes. Common mistakes were also identified during the implementation of the strategy, and they were dealt with on time during the application of the research. Students were trained to understand the main ideas in the subject, and then analyze these ideas into simple elements as found in the RAFT strategy to make it easier for students to write about these simple elements.

\section{Recommendations:}

1- Employing RAFT strategy to develop creative writing skills in different educational stages.

2- Providing a class in which students write freely on whatever subject they wish to write. This develops their positive attitudes towards writing.

3- Training teachers in the preparatory stage to employ the RAFT strategy to develop students' writing skills.

4- Training students to divide the essay into sub-elements to help them write better.

\section{Future Researches directions:}

- Determining the attitudes of students and teachers towards employing the RAFT strategy in developing creative writing skills for middle school students.

- Employing the RAFT strategy in teaching reading and literary texts to middle school students.

- Determining the effectiveness of the RAFT strategy in developing the reflective thinking skills of middle school students.

- Using the RAFT strategy to develop creative thinking and creative writing skills for middle school students, and the relationship between them.

\section{References:}

Abbas, L. Z. A., \& Abd Al-Sahib, I. M. (2021). The effectiveness of the RAFT strategy in the achievement of fourth-grade literary students in the subject of history. Psychology and Education Journal, 58(3), 19551961.

Abd Elaal, Reham (2016): The Effectiveness of (RAFT) "Strategy in Developing Environmental Values and Creative Writing Skills for second year Secondary School students". Journal of the Educational Society for Social Studies. Cairo. N (80). May. 118- 170.

Abd Elqader, Abd Elrazeq\& Ismaeel, Abd Elraheem (2015): "The Effectiveness of the SCAMPER Model in Developing the Creative Linguistic Performance of Linguistically Gifted Students in the Preparatory Stage". International Journal of Educational Research. United Arab Emirates University. Issue (37). 258-295

Abedelqader, Lina (2017): "Using RAFT Strategy to Improve EFL Learners' Writing Competency in in Paragraph Writing Courses at the University of Hail-KSA". International Journal of English Language Teaching. Vol. 5, No.8, PP: 37-49.

Abu Jabeen, Ata (2011): Creative Thinking Strategies and Skills in the Arabic Language: Practical Applications. Al Falah Library for Publishing and Distribution. Kuwait.

Abd, M. A., Dehham, S. H., \& Akbar, N. A (2020): "The Effective of RAFT Strategy One Improve the Performance of Iraq EFL 2ND intermediate-School Students in Reading Comprehension". Ilkogretim Online - Elementary Education Online, Vol 19 (Issue1):pp.628-638. Doi: doi 10.17051/ilkonline.2020.661893

Adam, A. A. S., \& Babiker, Y. O. (2015). "The Role of Literature in Enhancing Creative Writing from Teachers' Perspectives". English Language and Literature Studies, 5(1), 109-118 
Al Ahwal, Ahmed (2018): "The Effectiveness of a Program Based on Text towards Standards in Developing Creative Written Expression Skills for First Year Secondary Students". International Journal of Educational Research. College of Education. United Arab Emirates University. Volume (42). Issue 1 January. 191-243.

Al-Basess, Hatem (2011): Developing Reading and Writing Skills: Multiple Strategies for Teaching and Evaluation. Publications of the Syrian General Book Organization. Ministry of Culture. Damascus. Syria.

Al-Dulaimi, M., \& Hussein, M. (2020): "The effect of the RAFT strategy on the achievement of fifth-grade biological science students in chemistry". Journal of Educational and Scientific Studies. Faculty of Education. Iraqi University. Issue (15). Volume (2).

Al Hardani, Mohammed (2013): "The Effect of Teaching According to the MEDNIC Technique in Developing Creative Written Expression Skills among Female Students of Teacher Preparation Institutes and Their Attitudes towards Them”. [Unpublished Doctoral Dissertation]. Faculty of Education. Baghdad University. Iraq.

Alisa, Teza Peby\& Rosa, Rusdi Noor (2013): "R.A.F.T as a Strategy for Teaching Writing Functional Text to Junior High School Students”. Journal of English Language Teaching. Vol. 1. No.2. March. 1-9.

Al-Mahdawi, N\& Al-Smadi, O (2019). The Potential of RAFT Strategy for Improving Jordanian EFL

Students' Creative Writing. Lublin Studies in Modern Languages and Literature, 43(4), 105-113.

Al-Maliki, Fadel Bani (2020): "The effect of the RAFT imaginative writing strategy on reading comprehension and written expression for second-grade students in the intermediate school. Journal of the College of Basic Education. Issue (18) Volume (26). Iraq.

Al-Shammari, Waleed\& Al Hashemi, Abd Elrahman (2018): "The Effect of an educational Program Based on the Jensen Model of Brain-Based Learning on Improving Creative Writing Among Students in Saudi Arabia". Al-Quds Open University Journal of Educational and Psychological Research and Studies. Volume (7). Issue (21). April. 140-150.

Anggraini, R., \& Usman, B. (2017). Using Role, Audience, Format, and Topic (RAFT) in Teaching Writing. Research in English and Education Journal, 2(1), 19-26.

Barbot, B., Tan, M., Randi, J., Santa-Donato, G., \& Grigorenko, E. L. (2012). "Essential skills for creative writing: Integrating multiple domain-specific perspectives". Thinking Skills and Creativity, 7(3), 209-223.

CCRS Quarterly Meeting (2014): Instructional Strategies: All Students can learn. Alabama State Department of Education. U.S.A

Chen, T (2017): "Creative Writing and Critical Thinking be Used Together to Achieve Results". Advanced Creative Writing. Homested Schools. 6 April.

Cho, K., \& Schunn, C. D. (2007). Scaffolded writing and rewriting in the discipline: A web-based reciprocal peer review system. Computers \& Education, 48(3), 409-426.

Dakhel, Samaa (2018): “The Effect of the Developed Kohlberg and Cavarell Models in Developing Creative Writing Skills among Students of the College of Education". Journal of the College of Basic Education for Educational and Human Sciences. Faculty of Education. University of Babylon. Issue (41). Dec. 1818-1834

Dani, D., Litchfield, E., \& Hallman-Thrasher, A. (2018). Creative assessment: Using RAFT writing to assess students in a course on motion. The Science Teacher, 85(5), 1-3

El Sourani, Ahmad Iseifan (2017): "The Effective of Using RAFT Strategy in Improving English Writing Skills among Female Tenth Graders in Gaza". [Unpublished Master Thesis]. Faculty of Education. The Islamic University. Gaza.

Fawziah, Noor (2017): "The Effect of (RAFT) Strategy in Teaching Written Construction to Improve the Writing Skill of Islamic Middle School Students Dar Al-Hikma Tulong Agung". [Unpublished Master Thesis]. Arabic Language Department. College of Education and Educational Sciences. Government Islamic University. Indonesia.

Fijal, Mohammed (2010): Writing Skills (Teacher's Guide). Scientific Publication Department. King Saud University. Riyadh. Kingdom Saudi Arabia.

Ganinda, N. H., Mardiana, W., \& Anggraini, K. P. (2020). The Use of RAFT Strategy in Teaching Writing Report Text at Senior High School (Doctoral dissertation, University Islam Majapahit).

Hemmeter, M. L., \& Kaiser, A. P. (1990). Environmental Influences on Children's Language: A Model and Case Study. Education and Treatment of Children, 13(4), 331-346. http://www.jstor.org/stable/42899177

Hidayah, M. (2020). Using RAFT Strategy in Narrative Text to Improve Students Writing Skills for the Eighth Grade of MTS AL-USWAH BERGAS in the Academic Year 2019/2020. Graduating Paper. Teacher Training and Education Faculty State Institute for Islamic Studies (IAIN) Salatiga.

Hilfish, Gordon\& Smith, Filip (2012): Reflective thinking: a method of education. Trans: Al-Azzawi, Alsayed Muhammad and Shehab, Ibrahim Khalil. Dar Al-Nafaes for printing, publishing and distribution. Cairo. Egypt.

Idayanti, Ni Made (2014). "The Efficacy of RAFT in Improving Writing Skill of the Eighth Grade Students of 
SMPN 1 Mengwi In Academic Year 2013/2014”. [Unpublished Doctorate]. Faculty of Teacher Training and Education. Mahasaraswati Denpasar University. Indonesia.

Intharakasem, C. S., \& Boonhok, S. (2019, March). The Effects of Using RAFT Strategy on Thai Creative Writing Ability of Undergraduate Students. International Academic Multidisciplinary Research Conference in Vienna 2019.

Kabigting, R. P. (2020). Utilizing the RAFT Strategy: Its Effects on the Writing Performance of Filipino ESL Learners. Journal of English Teaching, 6(3), 173-182.

Khasawneh, Najwa (2012): "The Effectiveness of (RAFT) Strategy in Developing Some Spelling Concepts for Female Primary School Students in Taif”. Specialized International Journal. Oman. Volume 1, Number 6, July. 288-306.

Min, D. (2015). Research on the Factors Influencing Hong Kong Children's Language Acquisition. Studies in Literature and Language, 10(2), 68-71. DOI: http://dx.doi.org/10.3968/n

Morison, Gharey\& Ros, Steven\& Kimb, Girold (2012): Effective Instructional Design. Trans: Amani Dajani. Obeikan Library for Publishing. Riyadh.

Mukhaiyar, Desmawati\& Radjab, Desmawati (2013): “The Effect of Role, Audience, Format and Topic (RAFT) Strategy Towards Students' Ability in Paragraph Writing A Study at The First Year Students of College of Teacher Training And Education (STKIP) - PGRI WEST Sumatera”. Journal English Language Teaching (ELT). Volume 1 No. 2. July. 109-121.

Ola Ranjilita, D. P. (2021). The International of Using Role, Audience, Format, Topic (RAFT) Strategy Towards Students' Ability in Writing Analytical Exposition Text at The First Semester at The Eleventh Grade of SMA NEGERI 1 TALANG PADANG in The Academic Year of 2020/2021 (Doctoral dissertation, UIN RADEN INTAN LAMPUNG).

Olehlova, Ilona\& Priedite, Ines (2016): Creative Writing Cookbook. Estonian UNESCO Youth Association in cooperation. Estonia.

Parilasanti, N. M. E., Suarnajaya, I. W., \& Marjohan, A. (2014). "The Effect of RAFT Strategy and Anxiety Upon Writing Competency of the Seventh Grade Students of SMP Negeri 3 Mengwi in Academic Year 2013/2014". Jurnal Pendidikan Bahasa Inggris Indonesia, 2(1).1-9.

Pratiwi, Yoesis (2016): "The Use of RAFT Strategy in Teaching Writing Procedure Text at the Second Grade of Sman 3 Bandar Lampung". [Unpublished Doctorate]. Lampung University. Indonesia.

Qatamee, Yousef\& Allozey, Mariam (2008): Creative Writing for the Gifted: Model and Application. Dar Wael. Oman. Jordan.

Rivera, Daniela\& Pinilla, Johanna (2017): Promoting Self-Directed Learning by Means of Creative Writing. Faculty of Education. Bogota, 27 Oct.

Riyanti, Y. (2015). Improving Students' Descriptive Writing through Role, Audience, Format, and Topic (RAFT) Strategy (A Classroom Action Research in the Seventh Grade of SMP Paramarta Jombang). Faculty of Education and Teachers' Training of State Islamic University Syarif Hidayatullah Jakarta. Indonesia.

Seliem, S. I. M., Mohamed, M. F., \& Ali, R. M. I. (2020). The Effect of RAFT Strategy on Developing EFL Creative Writing Skills for the Third Year Governmental Language Preparatory School Students. Social\& Educational Studies Journal, 26355-311

Santa, C. M. (1988): Content Reading Including Study Systems: Reading, Writing and Studying across the Curriculum. Kendall/Hunt Publishing Company, 4050 Westmark Drive, Dubuque, IA 52002.

Taha, Eman\& Azahrani, Mona (2020): “The Effectiveness of (RAFT) Strategy through the (Blackboard) System in Developing Creative Writing Skills and the Trend towards the Children's Literature Course for Female Students/Teachers/Kindergarten majors". Educational Journal. Issue (75). July. Faculty of Education. Suhag University. Egypt.

The Quality Assurance Agency for Higher Education (2017): Subject Benchmark Statement for Creative Writing. Part A: Setting and maintaining academic standards. The Quality Assurance Agency for Higher Education. London. February.

Widiyati, Menik (2014): “The Effectiveness of RAFT (Role, Audience, Format and Topic) Technique to Teach Writing Viewed from Students' Creativity”. [Unpublished Master Degree]. Faculty of Teacher Training and Education. Sebelas

Zaier, Saad\& Dakhel, Samaa (2016): Modern Trends in Teaching Arabic. Al-Dar Al-Manhajyiah for publishing and distribution. First Print. Oman. Jordan. 